\title{
Role of microhabitats in food webs of benthic communities in a mangrove forest
}

\author{
K. Kon ${ }^{1, *}$, H. Kurokura ${ }^{1}$, K. Hayashizaki ${ }^{2}$ \\ ${ }^{1}$ Department of Global Agricultural Science, Graduate school of Agricultural and Life Sciences, The University of Tokyo, \\ 1-1-1 Yayoi Bunkyo-ku, Tokyo, 113-8657, Japan \\ ${ }^{2}$ School of Fisheries Sciences, Kitasato University, Sanriku, Ofunato, Iwate, 022-0101, Japan
}

\begin{abstract}
Mangrove benthic macro-invertebrate communities have access to various food sources. The food web in this system may not be based on homogenous mangrove detritus. In order to determine the contributions of mangrove leaf litter and microalgae to the benthic macro-invertebrate community, we analyzed carbon and nitrogen stable isotope ratios in primary producers (mangrove leaf litter, phytoplankton and microphytobenthos), particulate organic matter, sedimentary organic matter and benthic macro-invertebrates from 3 microhabitats (tidal creeks, inside forests and forest gaps) in a mangrove forest in Trang province, Thailand. The stable isotope values of particulate and sedimentary organic matter did not differ greatly between microhabitats, and values were relatively similar to mangrove leaf litter. Invertebrates from tidal creeks and inside forests also showed $\delta^{13} \mathrm{C}$ values similar to mangrove leaf litter, whereas invertebrate tissues from forest gaps were close to microphytobenthos $\delta^{13} \mathrm{C}$ values. Most invertebrates showed an enriched $\delta^{15} \mathrm{~N}$ value compared to the local particulate and sedimentary organic matter. These results indicate that invertebrates utilize different food sources in different microhabitats; they utilized mainly mangrove detritus in the tidal creeks and inside forests, but mainly microphytobenthos in the forest gaps. Moreover, the invertebrate biomass was highest in the forest gaps. This is important new information supporting the view that the mangrove food web is actually a diverse combination of webs based on a variety of resources, including homogenous mangrove detritus.
\end{abstract}

KEY WORDS: Mangrove forest $\cdot$ Benthic community Stable isotope $\cdot$ Food web $\cdot$ Microhabitat Resale or republication not permitted without written consent of the publisher

\section{INTRODUCTION}

Tropical mangrove forests may attain high levels of net primary production rates (Clough 1992), and there have been many studies assuming or concluding that mangrove trees are the dominant primary producers sustaining biological communities (e.g. Camilleri 1992). However, there is some uncertainty about the fate of leaf litter and its role in sustaining aquatic secondary production within and around the forests. Several recent studies (e.g. Bouillon et al. 2002) claim that the role of leaf litter has been overestimated. Therefore it is important to conduct an overall evaluation of different primary carbon sources available to the mangrove biological community in order to evaluate con- tradicting theories and to attain a better understanding of the mangrove ecosystem.

The primary producers (in addition to the trees) in mangrove forests are phytoplankton or microphytobenthos. Productivity of microalgae is relatively low in mangrove forests where light intensity is restricted (Alongi 1994), though they have been found to be an important food resource in other intertidal ecosystems, such as salt marshes (e.g. Page 1997), because of their high nutritional quality (e.g. Kathiresan \& Bingham 2001). Recent studies point out the importance of phytoplankton and microphytobenthos in mangrove forests (e.g. Bouillon et al. 2002), and several authors have suggested that their potential role in mangrove ecosystems deserves further study (e.g. Newell et al. 
1995, Bouillon et al. 2002). In mangrove forests, there are some microhabitats in which there is no light restriction, such as tidal creeks or forest gaps. Microalgae should have high productivity in these microhabitats, and therefore primary consumers inhabiting such habitats may utilize microalgae instead of detritus from mangroves.

Macro-invertebrate fauna inhabiting the intertidal zone in mangrove ecosystems are of particular importance in the food web (Robertson et al. 1992), because they are the connection between primary producers and higher trophic levels (e.g. Sheaves \& Molony 2000). Despite this potential importance of the faunal communities, only a limited number of studies have assessed carbon dynamics of the macro-invertebrates. We hypothesized that the dependency of the benthic macro-invertebrate community on mangrove-derived organic matter would vary by microhabitat, and that such differences would be related to the relative availability of alternative sources of organic matter, such as microphytobenthos or phytoplankton. Such a hypothesis would mean that the mangrove food web was not based on homogenous mangrove-derived detritus, but is actually heterogeneous and dependent on both mangrove detritus and microalgae.

Stable isotope analysis can offer valuable insights into the relative importance of different primary producers, but such studies have only rarely been conducted on mangrove-inhabiting invertebrates, or have been limited to a specific invertebrate species inhabiting specific habitats such as tidal creeks or inside forests (e.g. Newell et al. 1995, Chong et al. 2001, Bouillon et al. 2002). The stable isotope approach is based on the following assumptions: (1) the $\delta^{13} \mathrm{C}$ values of primary producers vary because of different photosynthetic pathways or different inorganic carbon sources, and (2) a consistent degree of fractionation occurs between the isotopic signal of the food source and that of the consumer. A small or negligible $\delta^{13} \mathrm{C}$ enrichment, ranging on average between 0 and $1 \%$, has been found to occur, and this difference is caused by variations in food source (e.g. DeNiro \& Epstein 1978). For $\delta^{15} \mathrm{~N}$, a higher fractionation of, on average, $2.6 \%$ o (Owens 1987) to $3.4 \%$ (Minagawa \& Wada 1984) is usually assumed, but the actual degree of fractionation may vary considerably, and several processes have been found to result in deviations from this general pattern (e.g. Scrimgeour et al. 1995).

We compared data on resource utilization patterns (as evident from $\delta^{13} \mathrm{C}$ and $\delta^{15} \mathrm{~N}$ analyses) of benthic macro-invertebrates from 3 microhabitats-a tidal creek, inside a forest, and a forest gap-in order to reveal the roles of these microhabitats in the food web dynamics of an intertidal mangrove forest.

\section{MATERIALS AND METHODS}

Study area. The research was conducted in an intertidal mangrove forest located around Sikao creek in Trang Province on the west coast of Thailand $\left(7^{\circ} 32^{\prime} \mathrm{N}\right.$, $\left.99^{\circ} 21^{\prime} \mathrm{E}\right)$ (Fig. 1). The forest is dominated by Rhizophora apiculata, and is subjected to semidiurnal tides with an amplitude of 1.0 to $2.5 \mathrm{~m}$. There were 3 microhabitats in the area: tidal creeks without mangroves, inside forest areas with mangroves, and forest gaps without mangroves. We set 2 transect lines from the tidal creek to the forest gap, passing through the inside forest area (Fig. 1). Transect 1 had 3 stations: TC1 in the tidal creek ( $\sim \mathrm{m}$ wide), IF1 inside the forest, and FG1 in the forest gap $\left(\sim 150 \mathrm{~m}^{2}\right)$. Transect 2 also had 3 stations: TC2 at the tidal creek ( $6 \mathrm{~m}$ wide), IF2 inside the forest, and FG2 in the forest gap $\left(\sim 1300 \mathrm{~m}^{2}\right)$. These stations had different light intensities under clear-sky conditions at midday: TC1: 2477.0, TC2: 2389.8, IF1: 54.1, IF2: 76.1, FG1: 2838.5, FG2: $2966.0 \mu \mathrm{mol}$ photons $\mathrm{m}^{-2}$ $\mathrm{s}^{-1}$ (MDS Mark V/L) in the dry season, and TC1: 2573.1, TC2: 2734.8, IF1: 54.0, IF2: 64.9, FG1: 3203.0, FG2: $3189.1 \mu \mathrm{mol}$ photons $\mathrm{m}^{-2} \mathrm{~s}^{-1}$ in the wet season. Sampling was carried out in March (dry season) and July/ August (wet season) 2005.

Sampling design. For all 6 stations, benthic macroinvertebrate sampling was from 5 replicated quadrats $(30 \times 30 \mathrm{~cm})$ randomly placed around the central area of each station during low tide. Macro-invertebrates were collected by excavating soil to $20 \mathrm{~cm}$ below the surface, following the procedure of Wada et al. (1978) that showed benthic macro-invertebrates were widely distributed in the top $20 \mathrm{~cm}$ surface layer of sediment. The sediment was sieved through a $0.5 \mathrm{~mm}$ mesh and the residue was preserved in $10 \%$ neutral buffered formalin fixative. The individual animals were later sorted from the sediments, identified to class level, counted and wet weighed in the laboratory. The 3 most abundant classes of invertebrates were identified to species level, as far as possible, and categorized as suspension feeders, or surface feeders (defined as consumers that obtain their food from the sediment surface; scavengers, surface grazers and deposit feeders), based on earlier studies (e.g. Alongi \& Sasekumar 1992) or on the form of mouth parts.

Stable isotope analyses. The most abundant species (3 to 5 species with highest density or biomass), suspended solids and surface sediments were collected at each station. Epifauna were collected by hand, and infauna were collected by excavating sediment at low tide $(\mathrm{n}=4)$. Suspended solids in surface water were sampled at high tide by filtration on precombusted glass fiber filters (Whatman GF/C) $(n=4)$. Surface sediments were obtained by scraping the top 1 to $2 \mathrm{~mm}$ of substratum at low tide $(\mathrm{n}=4)$. Primary 


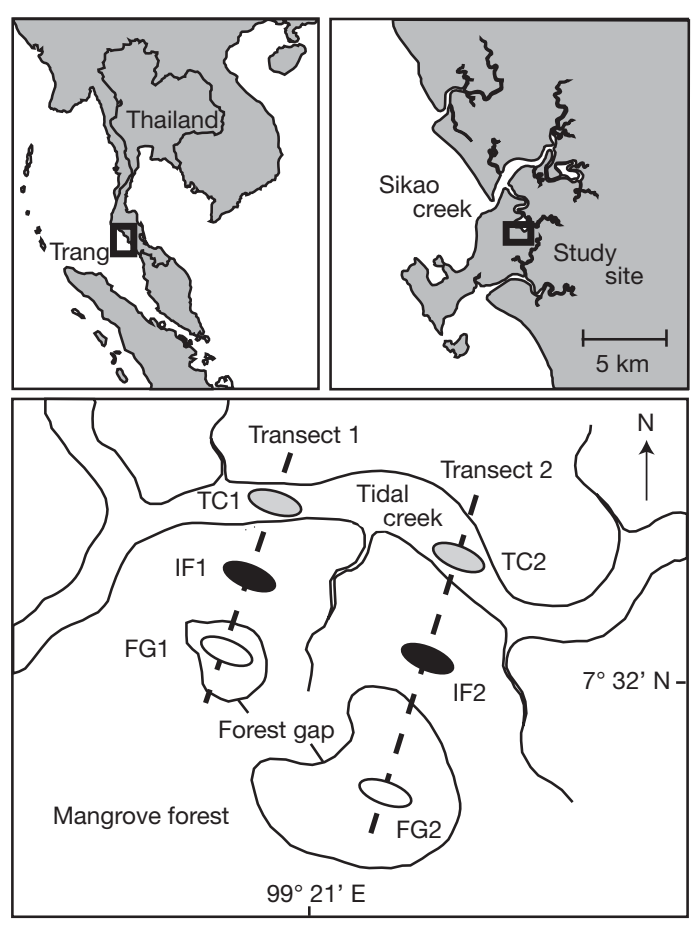

Fig. 1. Map of the sampling stations at Sikao Creek, Trang, Thailand. A total of 6 stations were located along 2 transects $(1,2)$, in the tidal creek (TC1, TC2), inside the forest (IF1, IF2), and forest gaps (FG1, FG2)

producers (potential sources of food or organic matter) were collected in all habitats. Mangrove leaf litter was collected by hand $(\mathrm{n}=4)$. Phytoplankton were obtained by pre-filtering seawater through a $100 \mu \mathrm{m}$ screen to remove any zooplankton and then filtering it through pre-combusted glass fiber filters (Whatman $\mathrm{GF} / \mathrm{F})(\mathrm{n}=4)$. Microphytobenthos cells were obtained by gently scraping them off the sediment where they formed a conspicuous layer $(\mathrm{n}=4)$, as reported by Bouillon et al. (2002). Microscope analysis confirmed that the scraped samples were almost entirely microalgae.

During transport to the field laboratory, all samples were kept in a cool box containing $-60^{\circ} \mathrm{C}$ coolants, then washed with distilled water. All samples except fauna were then immediately dried at $60^{\circ} \mathrm{C}$ for at least $48 \mathrm{~h}$. The faunal samples were processed before drying as follows: for some of the smaller crab species, the gut and intestinal system were first removed, and then muscle tissue of the body was used for the analysis; muscle tissue of larger crab species was taken directly from the chelae; and whole fleshy tissues of mollusks were analyzed after removal of shells. These selected faunal tissues were also dried at $60^{\circ} \mathrm{C}$ for at least $48 \mathrm{~h}$.

After drying, all samples were ground to a fine powder and treated with $0.1 \mathrm{~N} \mathrm{HCl}$ to remove carbonates that may have been present, and then re-dried, following the method of Jacob et al. (2005).

Stable isotope ratios were measured on an isotoperatio mass spectrometer (Thermo/Finnigan Delta plus $\mathrm{XP}$ ), and expressed relative to conventional standards, i.e. PeeDee Belemnite for carbon, and atmospheric air for nitrogen, as \%o values, defined as:

$$
\delta R=\frac{X_{\mathrm{SAMPLE}}-X_{\mathrm{STANDARD}}}{X_{\mathrm{STANDARD}}} \times 10^{3}(\% \circ)
$$

where $R={ }^{13} \mathrm{C}$ or ${ }^{15} \mathrm{~N}$, and $X={ }^{13} \mathrm{C} /{ }^{12} \mathrm{C}$ or ${ }^{15} \mathrm{~N} /{ }^{14} \mathrm{~N}$. Experimental precision (based on standard deviation of replicates of an alanine standard) was lower than $0.15 \%$ for both $\delta^{13} \mathrm{C}$ and $\delta^{15} \mathrm{~N}$.

Statistical analyses. Characteristics of the macroinvertebrates were expressed by number of classes, abundance (number of individuals), species richness of the 3 most abundant classes, and biomass (wet weight) per quadrat $\left(0.09 \mathrm{~m}^{2}\right)$. The data were analyzed by nested ANOVA as a function of season and microhabitat, with stations nested in microhabitats. Before the analyses, data were $\log (x+1)$ transformed in order to improve homogeneity of variances (Zar 1999). A nested ANOVA was also conducted for the stable isotope data, as a function of microhabitats and stations nested in microhabitats, to compare the values for suspended solids, surface sediments, and benthic macroinvertebrates when they appeared in more than 2 microhabitats.

\section{RESULTS}

The mean number of classes, densities and species richnesses of the 3 most abundant classes of animals were not significantly different between microhabitats or seasons (Table 1, Fig. 2a,b,c). However, the mean biomass was significantly greater in the forest gap, but there was no difference between seasons (Table 1, Fig. 2d).

The stable isotope ratios differed among primary producers: mangrove leaf litter (dry season: $\delta^{13} \mathrm{C}=$ $-29.1 \pm 0.7 \%$ o, $\delta^{15} \mathrm{~N}=-1.1 \pm 0.9 \%$; wet season: $\delta^{13} \mathrm{C}=$ $-29.2 \pm 0.1 \%$, $\delta^{15} \mathrm{~N}=2.0 \pm 0.2 \%$ ); phytoplankton (dry season: $\delta^{13} \mathrm{C}=-23.1 \pm 0.8 \%, \delta^{15} \mathrm{~N}=4.8 \pm 0.3 \%$; wet season: $\delta^{13} \mathrm{C}=-23.6 \pm 1.9 \%$, $\delta^{15} \mathrm{~N}=4.1 \pm 0.1 \%$ ); and microphytobenthos (dry season: $\delta^{13} \mathrm{C}=-18.2 \pm 0.6 \%$, $\delta^{15} \mathrm{~N}=1.2 \pm 0.5 \%$; wet season: $\delta^{13} \mathrm{C}=-17.5 \pm 0.3 \%$, $\delta^{15} \mathrm{~N}=1.2 \pm 0.3 \%$ ) (Figs. $3 \& 4$ ).

The isotopic values of suspended particulate organic matter (POM) did not differ significantly between microhabitats, and values were intermediate between those of phytoplankton and mangrove leaf litter (range of $\delta^{13} \mathrm{C}=-24.6$ to $-27.4 \%$, $\delta^{15} \mathrm{~N}=0.0$ to $6.3 \%$ in the dry season; $\delta^{13} \mathrm{C}=-28.3$ to $-26.9 \%$, $\delta^{15} \mathrm{~N}=0.6$ to $3.7 \%$ in 
Table 1. Summary of nested ANOVAs for number of classes, abundance, species richness and biomass of benthic macroinvertebrates per quadrat $\left(0.09 \mathrm{~m}^{2}\right)$ at Sikao Creek, Trang, Thailand

\begin{tabular}{|c|c|c|c|c|c|c|c|c|c|c|c|c|}
\hline \multirow[t]{2}{*}{ Source of variation } & \multicolumn{3}{|c|}{ Number of classes } & \multicolumn{3}{|c|}{ Abundance } & \multicolumn{3}{|c|}{ Species richness } & \multicolumn{3}{|c|}{ Biomass } \\
\hline & df & $F$ & $\mathrm{p}$ & df & $F$ & $\mathrm{p}$ & $\mathrm{df}$ & $F$ & $\mathrm{p}$ & df & $F$ & $\mathrm{p}$ \\
\hline Season & 1,48 & 0.03 & 0.861 & 1,48 & 0.38 & 0.540 & 1,48 & 1.22 & 0.276 & 1,48 & 1.10 & 0.299 \\
\hline Microhabitat & 2,48 & 0.50 & 0.608 & 2,48 & 1.67 & 0.198 & 2,48 & 0.03 & 0.969 & 2,48 & 15.10 & $<0.001$ \\
\hline Station (microhabitat) & 3,48 & 1.43 & 0.245 & 3,48 & 0.57 & 0.637 & 3,48 & 2.57 & 0.065 & 3,48 & 1.49 & 0.228 \\
\hline Season $\times$ Microhabitat & 2,48 & 1.60 & 0.212 & 2,48 & 5.09 & 0.009 & 2,48 & 0.78 & 0.464 & 2,48 & 0.72 & 0.492 \\
\hline Season $\times$ Station (microhabitat) & 3,48 & 0.78 & 0.509 & 3,48 & 0.68 & 0.568 & 3,48 & 1.51 & 0.225 & 3,48 & 0.37 & 0.772 \\
\hline
\end{tabular}
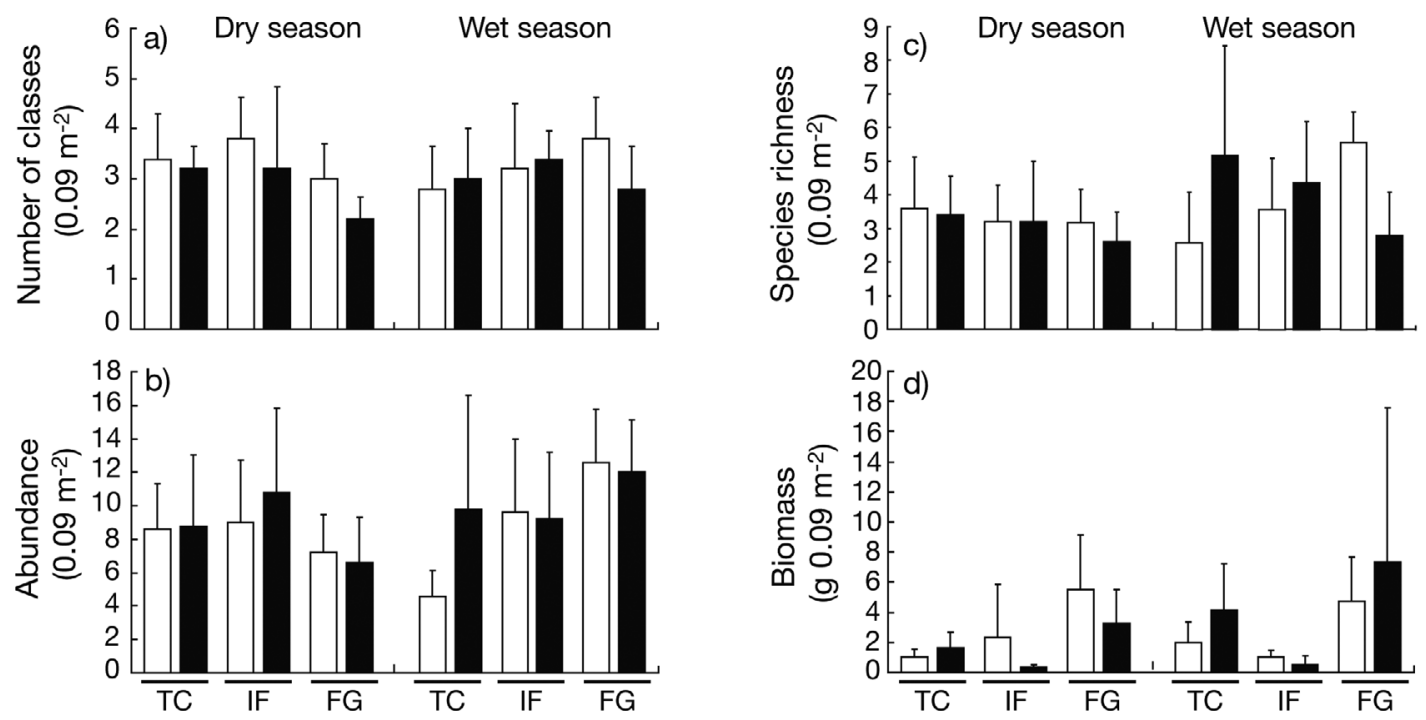

Fig. 2. Benthic macro-invertebrates at each station at Sikao Creek, Trang, Thailand, in each season. Mean + SD per quadrat $\left(0.09 \mathrm{~m}^{2}\right)$ of (a) number of classes, (b) abundance, (c) species richness in 3 most abundant classes, and (d) biomass. White and black bars indicate transects 1 and 2, respectively. TC: tidal creek; IF: inside forest; FG: forest gap

the wet season) (Fig. 3). Stable isotope ratios of surface sediment organic matter (SOM) in the dry season ranged as follows: $\delta^{13} \mathrm{C}=-24.7$ to $-27.7 \%$; $\delta^{15} \mathrm{~N}=-5.0$ to $0.7 \%$. In the wet season, these ranges were -25.6 to $-27.9 \%$ for $\delta^{13} \mathrm{C}$ and 0.4 to $2.6 \%$ for $\delta^{15} \mathrm{~N}$ (Fig. 4). The $\delta^{15} \mathrm{~N}$ values differed between microhabitats in the dry season (nested ANOVA $F_{2,24}=8.58, \mathrm{p}<0.01$, Fig. 4), and values for the forest gaps were closer to microphytobenthos values than those for other microhabitats (Fig. 4).

Suspension feeders from tidal creeks and inside forests had similar stable carbon isotope ratios (Table 2), with values between those of mangrove leaf litter and phytoplankton, similar to the values for POM (Fig. 3). The $\delta^{13} \mathrm{C}$ values for forest gap samples were intermediate between those of phytoplankton and microphytobenthos (Fig. 3). Laternula truncata appeared in the tidal creek and the inside forest microhabitats in the dry season, with no significant differences in $\delta^{13} \mathrm{C}$ and $\delta^{15} \mathrm{~N}$ signals between microhabitats.
The $\delta^{15} \mathrm{~N}$ values of suspension feeders were not enriched compared to the local particulate organic matter, except for Corbicula sp. and Unionidae sp. in the wet season (Fig. 3). Surface feeders from the tidal creek and inside forest locations had similar carbon stable isotope ratios (Table 3), and the values were intermediate between those of mangrove leaf litter and phytoplankton (Fig. 4). These values were close to that of SOM (Fig. 4). The $\delta^{13} \mathrm{C}$ values of invertebrates in the forest gaps (Table 3) were intermediate between those of phytoplankton and microphytobenthos (Fig. 4). Species that appeared in more than 2 microhabitats showed significantly different $\delta^{13} \mathrm{C}$ values between microhabitats in both seasons (nested ANOVA; Ovassiminea brevicula in the dry season, $F_{2,15}=46.82, \mathrm{p}<$ 0.001; O. brevicula in the wet season, $F_{2,15}=49.75, \mathrm{p}<$ 0.001; Cerithidea cingulata in the wet season, $F_{1,9}=$ 175.12, p < 0.001; Metaplax elegans in the wet season, $F_{1,9}=98.08, \mathrm{p}<0.001$ ) (Fig. 4). In these cases, the $\delta^{13} \mathrm{C}$ values from forest gaps were higher than those from 


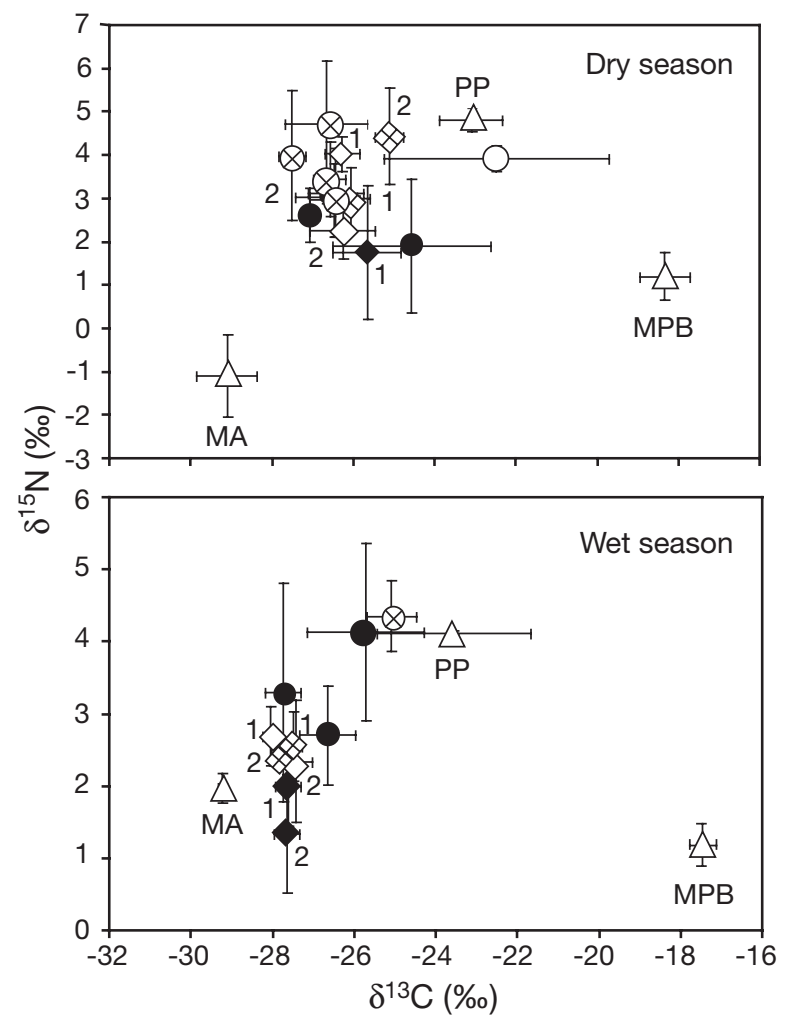

Fig. 3. $\delta^{15} \mathrm{~N}$ versus $\delta^{13} \mathrm{C}$ for primary producers $(\Delta), \operatorname{POM}(\diamond, \otimes$, $\checkmark$; suspended particulate organic matter), and suspension feeders $(\mathrm{O}, \otimes, \Theta)$ at Sikao Creek, Trang, Thailand. Black, crossed, and white symbols show samples from inside forest, tidal creek, and forest gap, respectively (except for primary producers). MA: mangroves; PP: phytoplankton; MPB: microphytobenthos; 1 : Transect $1 ; 2$ : Transect 2 . Error bars are SD.

See Table 2 for detailed values for suspension feeders

Table 2. Stable isotope ratio $( \pm \mathrm{SD})$ of suspension feeders at each station (Stn) at Sikao Creek, Trang, Thailand. See Fig. 1 for station abbreviations

\begin{tabular}{|llcc|}
\hline \multirow{2}{*}{ Stn } & Species & $\delta^{13} \mathrm{C}$ & $\delta^{15} \mathrm{~N}$ \\
\hline Dry season & & \\
TC1 & Wolffogebia inermis & $-27.5 \pm 0.3$ & $4.0 \pm 1.0$ \\
& Laternula truncata & $-26.8 \pm 0.4$ & $3.4 \pm 0.9$ \\
TC2 & Wolffogebia inermis & $-26.7 \pm 1.0$ & $4.7 \pm 1.4$ \\
& Laternula truncata & $-26.5 \pm 0.6$ & $3.0 \pm 0.8$ \\
IF1 & Laternula truncata & $-27.1 \pm 0.2$ & $2.6 \pm 0.6$ \\
& Corbicula sp. & $-24.6 \pm 1.9$ & $1.9 \pm 1.5$ \\
IF2 & Laternula truncata & $-26.6 \pm 0.8$ & $3.0 \pm 0.1$ \\
FG1 & Novaculina siamensis & $-22.5 \pm 2.8$ & $3.9 \pm 0.3$ \\
Wet season & & \\
TC2 & Unionidae sp. & $-25.1 \pm 0.6$ & $4.4 \pm 0.5$ \\
IF1 & Wolffogebia inermis & $-27.7 \pm 0.4$ & $3.3 \pm 1.5$ \\
& Corbicula sp. & $-25.7 \pm 1.4$ & $4.1 \pm 1.2$ \\
IF2 & Laternula truncata & $-26.6 \pm 0.7$ & $2.7 \pm 0.7$ \\
\multicolumn{4}{l}{} \\
\hline
\end{tabular}

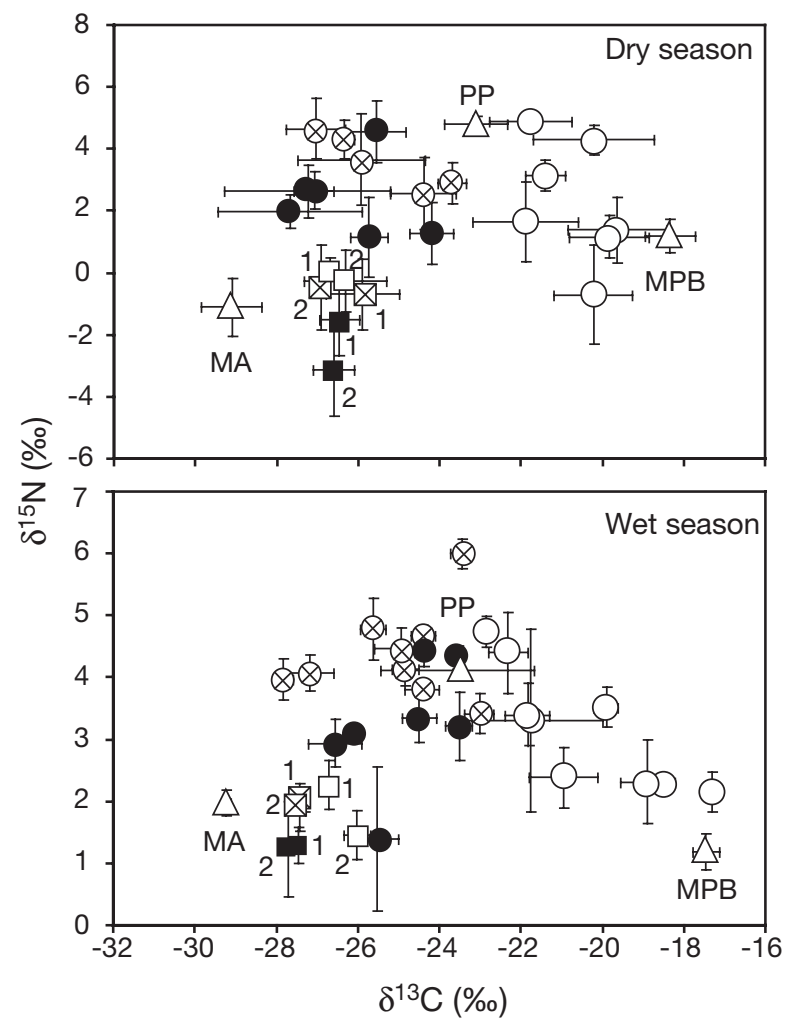

Fig. 4. $\delta^{15} \mathrm{~N}$ versus $\delta^{13} \mathrm{C}$ for primary producers $(\Delta), \operatorname{SOM}(\diamond, \otimes$, $\checkmark$; surface sediment organic matter), and surface feeders $(O$, $\otimes$, @) at Sikao Creek, Trang, Thailand. Black, crossed, and white symbols show samples from inside forest, tidal creek, and forest gap, respectively (except for primary producers). Error bars are SD. See Fig. 3 for abbreviations and Table 3 for detailed values for surface feeders

other microhabitats, but such differences were not observed for $\delta^{15} \mathrm{~N}$ values. The $\delta^{15} \mathrm{~N}$ values of surface feeders were 1.1 to $5.2 \%$ higher than those of the local sedimentary organic matter, except for Uca urvillei in the dry season and Uca juveniles in the wet season (Fig. 3).

\section{DISCUSSION}

The $\delta^{13} \mathrm{C}$ values for mangrove leaf litter were typical for terrestrial $\mathrm{C}_{3}$-plants and within the range for leaves of various mangrove species (e.g. Newell et al. 1995, Bouillon et al. 2002). The $\delta^{13} \mathrm{C}$ signal of phytoplankton was also similar to those of planktonic algae from mangroves and other intertidal ecosystems (e.g. Chong et al. 2001). The $\delta^{13} \mathrm{C}$ signature of the microphytobenthos was very different from mangrove leaf litter and phytoplankton, but again similar to those reported for benthic algae from mangroves and other intertidal ecosys- 
tems (e.g. Newell et al. 1995, Page 1997). Although previous studies (e.g. Couch 1989, Hamilton et al. 2005) used more sophisticated techniques for the sampling of phytoplankton and microphytobenthos than we did, the close correspondence of our $\delta^{13} \mathrm{C}$ data to values reported in the literature indicates that our results for microalgae are likely valid.

Table 3. Stable isotope ratio $( \pm \mathrm{SD})$ of surface feeders (defined as consumers that obtain food from sediment surface: scavengers, surface grazers and deposit feeders) at each station at Sikao Creek, Trang, Thailand. See Fig. 1 for station abbreviations

\begin{tabular}{|c|c|c|c|}
\hline Stn & Species & $\delta^{13} \mathrm{C}$ & $\delta^{15} \mathrm{~N}$ \\
\hline \multicolumn{4}{|c|}{ Dry season } \\
\hline TC1 & $\begin{array}{l}\text { Metaplax elegans } \\
\text { Ovassiminea brevicula } \\
\text { Cylindrotis quadrasi }\end{array}$ & $\begin{array}{l}-23.7 \pm 0.3 \\
-25.9 \pm 1.5 \\
-27.0 \pm 0.7\end{array}$ & $\begin{array}{l}2.9 \pm 0.7 \\
3.6 \pm 1.5 \\
4.6 \pm 1.0\end{array}$ \\
\hline TC2 & $\begin{array}{l}\text { Metaplax distincta } \\
\text { Sphaeromatidae sp.1 }\end{array}$ & $\begin{array}{l}-24.4 \pm 0.8 \\
-26.3 \pm 0.2\end{array}$ & $\begin{array}{l}2.6 \pm 1.2 \\
4.3 \pm 0.6\end{array}$ \\
\hline IF1 & $\begin{array}{l}\text { Uca bengali } \\
\text { Serenella indica } \\
\text { Ovassiminea brevicula }\end{array}$ & $\begin{array}{l}-24.2 \pm 0.5 \\
-25.7 \pm 0.4 \\
-27.2 \pm 2.0\end{array}$ & $\begin{array}{l}1.3 \pm 1.0 \\
1.1 \pm 1.3 \\
2.6 \pm 0.9\end{array}$ \\
\hline IF2 & $\begin{array}{l}\text { Uca bengali } \\
\text { Sphaeromatidae sp. } 2 \\
\text { Ovassiminea brevicula }\end{array}$ & $\begin{array}{l}-25.6 \pm 0.7 \\
-27.7 \pm 1.8 \\
-27.1 \pm 0.5\end{array}$ & $\begin{array}{l}4.5 \pm 1.0 \\
2.0 \pm 0.9 \\
2.6 \pm 0.6\end{array}$ \\
\hline FG1 & $\begin{array}{l}\text { Uca urvillei } \\
\text { Uca forcipata } \\
\text { Metaplax distincta } \\
\text { Ovassiminea brevicula }\end{array}$ & $\begin{array}{l}-20.2 \pm 1.0 \\
-19.8 \pm 1.0 \\
-21.9 \pm 1.3 \\
-21.3 \pm 0.5\end{array}$ & $\begin{array}{r}-0.7 \pm 1.6 \\
1.2 \pm 0.7 \\
1.6 \pm 1.3 \\
3.1 \pm 0.5\end{array}$ \\
\hline FG2 & $\begin{array}{l}\text { Uca annulipes } \\
\text { Cerithidea cingulata } \\
\text { Ovassiminea brevicula }\end{array}$ & $\begin{array}{l}-19.6 \pm 1.2 \\
-21.8 \pm 1.0 \\
-20.2 \pm 1.5\end{array}$ & $\begin{array}{l}1.4 \pm 1.1 \\
4.9 \pm 0.2 \\
4.3 \pm 0.5\end{array}$ \\
\hline \multicolumn{4}{|c|}{ Wet season } \\
\hline TC1 & $\begin{array}{l}\text { Uca forcipata } \\
\text { Metaplax elegans } \\
\text { Metaplax distincta } \\
\text { Cerithidea cingulata } \\
\text { Ovassiminea brevicula }\end{array}$ & $\begin{array}{l}-23.0 \pm 0.4 \\
-24.8 \pm 0.3 \\
-23.5 \pm 0.3 \\
-27.1 \pm 0.6 \\
-25.6 \pm 0.3\end{array}$ & $\begin{array}{l}3.4 \pm 0.3 \\
4.1 \pm 0.3 \\
6.0 \pm 0.2 \\
4.1 \pm 0.3 \\
4.8 \pm 0.5\end{array}$ \\
\hline TC2 & $\begin{array}{l}\text { Uca urvillei } \\
\text { Metaplax elegans } \\
\text { Cerithidea cingulata } \\
\text { Laemodonta panctatostriata }\end{array}$ & $\begin{array}{l}-24.4 \pm 0.4 \\
-24.4 \pm 0.3 \\
-27.8 \pm 0.3 \\
-24.9 \pm 0.6\end{array}$ & $\begin{array}{l}3.8 \pm 0.1 \\
4.7 \pm 0.2 \\
4.0 \pm 0.3 \\
4.5 \pm 0.3\end{array}$ \\
\hline IF1 & $\begin{array}{l}\text { Uca bengali } \\
\text { Perisesarma indiarum } \\
\text { Ovassiminea brevicula }\end{array}$ & $\begin{array}{l}-23.5 \pm 0.3 \\
-24.4 \pm 0.2 \\
-26.5 \pm 0.7\end{array}$ & $\begin{array}{l}3.2 \pm 0.5 \\
4.4 \pm 0.2 \\
2.9 \pm 0.4\end{array}$ \\
\hline IF2 & $\begin{array}{l}\text { Uca bengali } \\
\text { Perisesarma indiarum } \\
\text { Grapsidae juveniles } \\
\text { Ovassiminea brevicula }\end{array}$ & $\begin{array}{l}-24.5 \pm 0.4 \\
-26.1 \pm 0.1 \\
-23.5 \pm 0.1 \\
-25.5 \pm 0.5\end{array}$ & $\begin{array}{l}3.3 \pm 0.4 \\
3.1 \pm 0.1 \\
4.4 \pm 0.1 \\
1.4 \pm 1.2\end{array}$ \\
\hline FG1 & $\begin{array}{l}\text { Uca urvillei } \\
\text { Uca forcipata } \\
\text { Uca juveniles } \\
\text { Metaplax elegans } \\
\text { Ovassiminea brevicula }\end{array}$ & $\begin{array}{l}-21.8 \pm 0.5 \\
-20.0 \pm 0.3 \\
-18.9 \pm 0.7 \\
-22.9 \pm 0.2 \\
-21.7 \pm 1.8\end{array}$ & $\begin{array}{l}3.4 \pm 0.5 \\
3.5 \pm 0.3 \\
2.3 \pm 0.7 \\
4.7 \pm 0.2 \\
3.3 \pm 1.5\end{array}$ \\
\hline FG2 & $\begin{array}{l}\text { Uca forcipata } \\
\text { Uca annulipes } \\
\text { Cerithidea cingulata } \\
\text { Ovassiminea brevicula }\end{array}$ & $\begin{array}{l}-18.5 \pm 0.1 \\
-17.3 \pm 0.2 \\
-22.3 \pm 0.5 \\
-20.9 \pm 0.8\end{array}$ & $\begin{array}{l}2.3 \pm 0.1 \\
2.2 \pm 0.3 \\
4.4 \pm 0.7 \\
2.4 \pm 0.5\end{array}$ \\
\hline
\end{tabular}

The POM had similar stable isotope values in the different microhabitats, falling between phytoplankton and mangrove leaf litter values (Fig. 3), indicating that the POM, which was spread extensively throughout the intertidal mangrove forest, consisted of both phytoplankton and mangrove detritus. Although SOM had similar stable isotope values to the mangrove leaf litter in all microhabitats, the values in forest gaps tended to be slightly more enriched (Fig. 4). This suggests that SOM is mainly composed of mangrove-derived detritus, while in forest gaps a part of the sediment is derived from the biomass of microphyobenthos, which can utilize the high light intensity on the sediment surface. Light intensity is also high in tidal creeks, but high turbidity contributes to the low light levels that limit productivity of benthic microalgae at the bottom of creeks (Alongi 1994). Thus, long-lasting floods and high tides likely restrict the microphytobenthos biomass in tidal creeks.

Generally, $\delta^{13} \mathrm{C}$ values are used to estimate the source of consumers' diets because enrichment caused by fractionation or by metabolic effects is small or negligible (enrichment is only 0 to $1 \%$; e.g. DeNiro \& Epstein 1978). For $\delta^{15} \mathrm{~N}$ values, a higher enrichment by fractionation ranging from 2.6\% (Owens 1987) to $3.4 \%$ (Minagawa \& Wada 1984) is usually assumed, and is used to estimate consumer trophic levels. In our study, suspension feeders from the tidal creeks and inside forests had similar $\delta^{13} \mathrm{C}$ values, close to those of local suspended organic matter. The values were between those of mangrove leaf litter and phytoplankton, and different from those of forest gaps which fell between the values for phytoplankton and microphytobenthos (Fig. 3). There was also no difference in $\delta^{13} \mathrm{C}$ values for Laternula truncata between the tidal creek and inside forest locations in the dry season (Table 2). This indicates that the food source of suspension feeders in the tidal creeks and inside forests was local suspended organic matter, which is a mixture of mangrovederived detritus and phytoplankton. In contrast, the food sources for animals in forest gaps were phytoplankton and microphytobenthos. Resuspension of benthic microalgae is one of the ingestion and/or assimilation processes used by suspension feeders, as reported for other intertidal ecosystems (e.g. Kang et al. 1999). In the forest gaps there was a slightly enriched microphytobenthos biomass (Fig. 4), and resuspension of this likely occurred more frequently than in other microhabitats. The $\delta^{15} \mathrm{~N}$ values of suspension feeders were not enriched in comparison to local particulate organic matter, except for Corbicula sp. and Unionidae sp. in the wet season (Fig. 3). Recent studies suggest that the actual degree of fractionation of $\delta^{15} \mathrm{~N}$ may vary considerably, and several processes result in deviations from this general pattern (e.g. Scrimgeour 
et al. 1995). Indeed, Bouillon et al. (2002) found that some invertebrates in other intertidal mangrove ecosystems had greatly depleted $\delta^{15} \mathrm{~N}$ values compared to their food sources. These facts suggest that the $\delta^{15} \mathrm{~N}$ data for some of the suspension feeder species in our study were the result of low $\delta^{15} \mathrm{~N}$ fractionation. However, we need to conduct further feeding experiments to confirm the isotopic fractionation.

The $\delta^{13} \mathrm{C}$ values for surface feeders from the tidal creeks and inside forests were similar, close to those of the local sedimentary organic matter, and were between the values for the mangrove leaf litter and phytoplankton. In contrast, the $\delta^{13} \mathrm{C}$ values of surface feeders in forest gaps lay between those of phytoplankton and microphytobenthos (Fig. 4). For some animals occurring in several microhabitats, like Ovassiminea brevicula, Cerithidea cingulata or Metaplax elegans, there was significant intraspecific variation in $\delta^{13} \mathrm{C}$ values between collections from forest gaps and those from tidal creeks and inside forests (Table 3). These results strongly suggest that the major food source differed between the microhabitats; surface feeders from tidal creeks and inside forests likely assimilated local sedimentary organic matter, which consisted mainly of mangrove-derived detritus plus sedimented phytoplankton, whereas animals from forest gaps appear to have fed on planktonic and benthic microalgae. Although there were no enriched $\delta^{15} \mathrm{~N}$ values for Uca urvillei in the dry season or Uca juveniles in the wet season, probably also due to low $\delta^{15} \mathrm{~N}$ fractionation (as described above for some of the suspension feeders), the other $\delta^{15} \mathrm{~N}$ results support the theory of different food sources between habitats, because the $\delta^{15} \mathrm{~N}$ values of most surface feeders were enriched compared to the local sedimentary organic matter (Fig. 4). There were likely 2 processes of ingestion and/or assimilation of microphytobenthos by surface feeders in the forest gaps. The first is selective feeding. The fiddler crab genus Uca selects diatoms or bacteria by sorting mechanisms associated with the buccal frame. The mechanism does not select for mangrovederived detritus from surface sediments (Meziane et al. 2002). In the forest gaps, this process occurred frequently, producing slightly enriched microphytobenthos (Fig. 4). Another possible explanation for the strong impact by benthic microalgae is the difference in ingestion efficiency between mangrove-derived detritus and microalgae. Usually, there are large amounts of indigestible or toxic substances, such as cellulose or tannin, in the fresh detritus of vascular plants (Lalli \& Parsons 1993) making mangrove litter less easily digestible than microalgae. Accordingly, other invertebrates that do not have selective feeding systems, such as $O$. brevicula or $C$. cingulata, will assimilate proportionately more microalgae when feeding on material consisting of both mangrovederived detritus and microalgae. Robertson \& Blaber (1992) reported that while microalgae may make only a small contribution to total productivity in intertidal mangrove ecosystems, they might be critical for supporting higher trophic levels. This view is reinforced when considering the high nutritional quality of microalgae (e.g. Kathiresan \& Bingham 2001), and the fact that the highest biomass occurred in forest gaps (Table 1, Fig. 2), which is likely attributable to the high nutritional quality of the microalgae.

\section{CONCLUSIONS}

Our data strongly suggest that the food sources of the intertidal mangrove macro-invertebrate communities differed between microhabitats. Considering that benthic macro-invertebrates act as a link between primary producers and higher trophic levels (e.g. Robertson et al. 1992, Sheaves \& Molony 2000), our results indicate that the mangrove ecosystem consists of 2 different food webs, in addition to the phytoplanktonbased food web which was utilized in all microhabitats. One web was based on mangrove-derived detritus in the tidal creeks and inside forests, and the other was based on microphytobenthos in the forest gaps. Moreover, the forest gaps appeared to be quite an important environment for secondary production, supporting the most abundant biomass of macro-invertebrates (Table 1, Fig. 2). These results provide new insights into mangrove food webs, showing that there is no homogenous mangrove-derived detritus food web. Rather, there are diverse food webs consisting of mangrove detritus food webs and a microalgal food web that supports the most abundant biomass of consumers.

Acknowledgements. We are grateful to S. Tanyaros, P. Tongununui and the staff of the Faculty of Science and Fisheries, Rajamangala Institute of Technology, for assistance with the fieldwork. Constructive comments on the manuscript from I. McTaggart, M. Sano, S. Ishikawa and members of the Laboratory of Global Fisheries Science were much appreciated. Special thanks to the National Research Council of Thailand for granting permits to conduct this study in Thailand. The present work was supported in part by a Grantin-Aid for International Scientific Research from the Japan Society for the Promotion of Science (No. 15255017).

\section{LITERATURE CITED}

Alongi DM (1994) Zonation and seasonality of benthic primary production and community respiration in tropical mangrove forests. Oecologia 98:320-327

Alongi DM, Sasekumar A (1992) Benthic communities. In: Robertson AI, Alongi DM (eds) Tropical mangrove ecosys- 
tems. American Geophysical Union, Washington, DC, p 137-171

Bouillon S, Koedam N, Raman AV, Dehairs F (2002) Primary producers sustaining macro-invertebrate communities in intertidal mangrove forests. Oecologia 130:441-448

Camilleri JC (1992) Leaf-litter processing by invertebrates in a mangrove forest in Queensland. Mar Biol 114:139-145

Chong VC, Low CB, Ichikawa T (2001) Contribution of mangrove detritus to juvenile prawn nutrition: a dual stable isotope study in a Malaysian mangrove forest. Mar Biol 138:77-86

Clough BF (1992) Primary productivity and growth of mangrove forests. In: Robertson AI, Alongi DM (eds) Tropical mangrove ecosystems. American Geophysical Union, Washington, DC, p 225-249

Couch CA (1989) Carbon and nitrogen stable isotopes of meiobenthos and their food resources. Estuar Coast Shelf Sci 28:433-441

DeNiro MJ, Epstein S (1978) Influence of diet on distribution of carbon isotopes in animals. Geochim Cosmochim Acta 42:495-506

Hamilton SK, Sippel SJ, Bunn SE (2005) Separation of algae from detritus for stable isotope or ecological stoichiometry studies using density fractionation in colloidal silica. Limnol Oceanogr: Methods 3:149-157

Jacob U, Mintenbeck K, Brey T, Knust R, Beyer K (2005) Stable isotope food web studies: a case for standardized sample treatment. Mar Ecol Prog Ser 287:251-253

Kang CK, Sauriau PG, Richard P, Blanchard GF (1999) Food sources of the infaunal suspension-feeding bivalve Cerastoderma edule in a muddy sandflat of Marennes-Oleron Bay, as determined by analyses of carbon and nitrogen stable isotopes. Mar Ecol Prog Ser 187:147-158

Kathiresan K, Bingham BL (2001) Biology of mangroves and mangrove ecosystems. Adv Mar Biol 40:81-251

Lalli CM, Parsons TR (1993) Biological oceanography: an

Editorial responsibility: Howard Browman (Associate Editorin-Chief), Storebø, Norway introduction, 2nd edn. Butterworth-Heineman, Oxford

Meziane T, Sanabe MC, Tsuchiya M (2002) Role of fiddler crabs of a subtropical intertidal flat on the fate of sedimentary fatty acids. J Exp Mar Biol Ecol 270:191-201

Minagawa M, Wada E (1984) Stepwise enrichment of ${ }^{15} \mathrm{~N}$ along food-chains-further evidence and the relation between $\delta^{15} \mathrm{~N}$ and animal age. Geochim Cosmochim Acta 48:1135-1140

Newell RIE, Marshall N, Sasekumar A, Chong VC (1995) Relative importance of benthic microalgae, phytoplankton, and mangroves as sources of nutrition for penaeid prawns and other coastal invertebrates from Malaysia. Mar Biol 123:595-606

Owens NJP (1987) Natural variations in ${ }^{15} \mathrm{~N}$ in the marine environment. Adv Mar Biol 24:389-451

Page HM (1997) Importance of vascular plant and algal production to macro-invertebrate consumers in a southern California salt marsh. Estuar Coast Shelf Sci 45:823-834

Robertson AI, Blaber SJM (1992) Plankton, epibenthos and fish communities. In: Robertson AI, Alongi DM (eds) Tropical mangrove ecosystems. American Geophysical Union, Washington, DC, p 173-224

Robertson AI, Alongi DM, Boto KG (1992) Food chains and carbon fluxes. In: Robertson AI, Alongi DM (eds) Tropical mangrove ecosystems. American Geophysical Union, Washington, DC, p 293-326

Scrimgeour CM, Gordon SC, Handley LL, Woodford JAT (1995) Trophic levels and anomalous $\delta^{15} \mathrm{~N}$ of insects on raspberry (Rubus-Idaeus L). Isot Environ Health Stud 31:107-115

Sheaves M, Molony B (2000) Short-circuit in the mangrove food chain. Mar Ecol Prog Ser 199:97-109

Wada K, Komiyama A, Ogino K (1978) Underground vertical distribution of macrofauna and root in a mangrove forest of southern Thailand. Publ Seto Mar Biol Lab 32:329-333

Zar JH (1999) Biostatistical analysis, 4th edn. Prentice Hall, Upper Saddle River, NJ

Submitted: July 13, 2006; Accepted: November 19, 2006

Proofs received from author(s): May 28, 2007 